\title{
MONO-CRYSTALLINE SILICON SOLAR CELL FABRICATION IN BANGLADESH
}

\author{
Md.Asrafusjaman ${ }^{1}$, Kutub Uddin ${ }^{2}$, Galib Hashmi ${ }^{3}$, Md. Abdur Rafiq Akand ${ }^{4}$

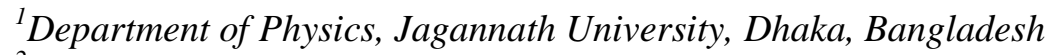 \\ ${ }^{2}$ Department of Physics, Jagannath University, Dhaka, Bangladesh \\ ${ }^{3}$ Department of Electrical and Electronic Engineering, University of Dhaka, Bangladesh \\ ${ }^{4}$ Solar Cell Fabrication \& Research Division, Institute of Electronics, Bangladesh Atomic Energy Commission, Saver, \\ Dhaka, Bangladesh
}

\begin{abstract}
Bangladesh, a tropical country, undergoes an average daily irradiation of $5 \mathrm{kWh} / \mathrm{m}^{2} /$ day which indicates solar energy is strong in this region and converting this solar energy into electricity may be one of the crucial solutions to eradicate the power crisis in Bangladesh. As solar cell converts, solar energy into electricity, this paper presents fabrication of monocrystalline silicon solar cell in Bangladesh to utilize the $5 \mathrm{kWh} / \mathrm{m}^{2} /$ day irradiation. The fabrication of monocrystalline solar cell was done in Bangladesh Atomic Energy Commission (BAEC), solar cell research division laboratory. A p-type pseudo-square shaped silicon wafer $\left(150 \times 150 \mathrm{~mm}^{2}\right.$, mono crystalline silicon wafer, with $200 \mu \mathrm{m}$ thickness and $\langle 100\rangle$ orientation was used in the present study for fabrication of solar cell. This paper also discussed about texturing and cleaning of the wafer, which was performed using different chemical solutions. The morphology of raw, cleaned and textured silicon wafer surface has been studied using scanning electron microscopy. Result shows, pyramid type structures are formed on the textured surface which reduces reflection and helps to trap more light. By using, liquid POCl 3 , hosphorous diffusion was carried out in a diffusion chamber to form $p$ - $n$ junction of solar cell. A screen printer was used for metallization process. Rapid thermal annealing (RTA) furnace was used for contact formation. Finally, the solar cells efficiency was measured by LIV (Light intensity-Current-Voltage) tester. Results show that, with an active surface area of $161 \mathrm{~cm}^{2}$, monocrystalline solar cell has efficiency ( $\eta$ ) of $6.89 \%$ and fill factor of $32.89 \%$.
\end{abstract}

Keywords: Solar energy, Fabrication, Silicon wafer, Phosphorus diffusion, Efficiency. ****

\section{INTRODUCTION}

In every year 33 billion metric tons of carbon dioxide is generated [1] by burning fossil fuel and it is due to the fact that, $80 \%$ of world energy utilizes fossil fuel [2]. Therefore, it is one of the primary cause of global warming and the world as of already saw the unfriendly impact of an unnatural weather change due to global warming. Presently the time has come to contemplate our method for electricity production. Instead of our reliance on fossil fuel, maximum utilization of solar energy can be the best alternative to fossil fuel in terms of environment pollution, availability and long-lasting of resource.

Bangladesh, being a tropical country, undergoes an average daily irradiation is $5 \mathrm{kWh} / \mathrm{m}^{2} /$ day. More than 65,000 solar home systems are now being installed every month and around 4 million off grid solar home systems have been operational in the rural areas of Bangladesh till April 2016.There is a huge demand of solar panel in the remote area but still in Bangladesh solar cell is not fabricated. This paper discusses the fabrication steps of mono-crystalline silicon solar cell in Bangladesh. A p- type silicon wafer with $200 \mu \mathrm{m}$ thickness was used in the fabrication process. Diffusion technique like phosphorous diffusion using phosphorus oxy- chloride $\left(\mathrm{POCl}_{3}\right)$ gas source is discussed. This paper also elaborates the fabrication steps like cleaning, texturing and metallization. Screen printer was used for metallization process. The efficiency of first fabricated mono- crystalline silicon solar cell is found very low, which is $0.8 \%$, but optimizing the instrument setup, and fabrication steps, finally $6.89 \%$ efficiency was achieved.

\section{STEPS OF MONO-CRYSTALLINE SILICON SOLAR CELL}

The majority of silicon solar cell production is currently based upon a very standardized process which is forming a $\mathrm{p}-\mathrm{n}$ junction; cover the front surface with silver busbars and fingers and covering the full- area of back of the wafer with aluminum paste a process called metallization [3]. The fabrication process of Si solar cell in Bangladesh starts with a $200 \mu \mathrm{m}$ thick, p-type pseudo-square mono-crystalline silicon wafer with an area of $150 \times 150 \mathrm{~mm}^{2}$. The pseudosquare silicon wafers are show in figure 1 . 


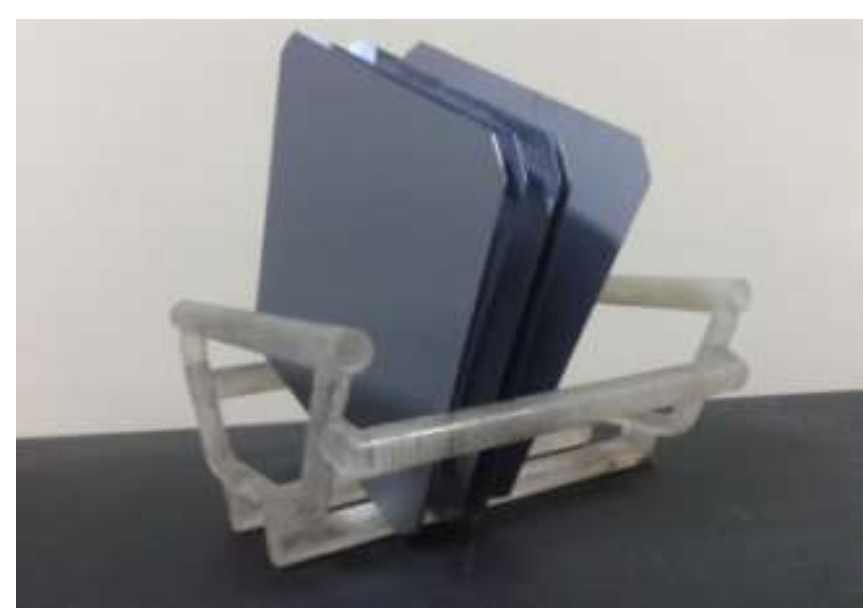

Fig- 1: P-type mono-crystalline silicon wafers.

Cutting silicon into wafers leaves the surface covered with cutting dust, particles, waste, organic compound, ionic compound etc. and the surface is damaged due to the action of the saw. For this reason wafers are needed to be cleaned in a hot chemical solution to removes the surface contamination. The cleaning process is known as saw damage removal process. Moreover after saw damage removal process texturing on solar cell is done to reduce reflection and enhance light absorption [4], [5]. After cleaning and texturing, the edge isolation was done to remove p-n junction short circuit. Edge isolation was done by using an edge isolation barrier paste. Next, N-type layer was formed upon a p- type silicon wafer using phosphorus diffusion technique in diffusion chamber [6]. After formation of $\mathrm{p}-\mathrm{n}$ junction, metallization process is necessary for output contact terminal. At front surface of solar cell silver and at the back surface aluminum busbars and fingers were printed using screen printing machine. Afterwards, the silver and aluminum busbars and fingers along with solar cell were heated at very high temperature in rapid thermal annealing furnace, for the formation of contact.

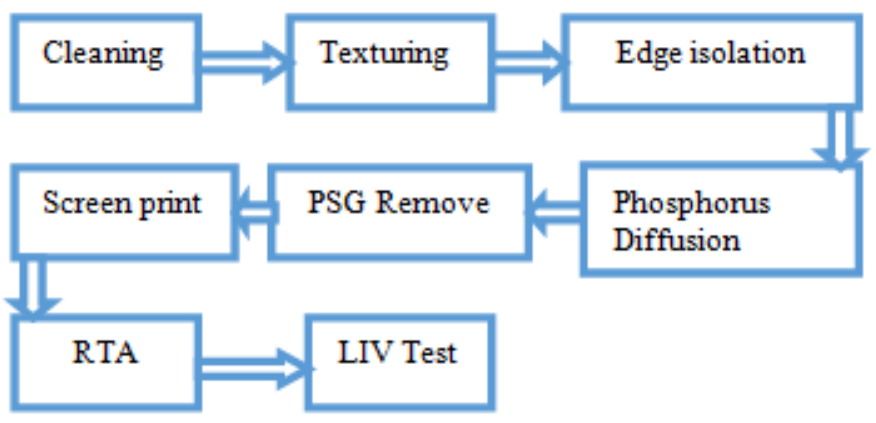

Fig-2: Block diagram of the fabrication steps of monocrystalline solar cell in Bangladesh.

Figure 2 illustrates the mono-crystalline solar cell fabrication process in Bangladesh. All the steps involved in fabrication of solar cell in Bangladesh are elaborately discussed in the following sections of the paper.

\subsection{Cleaning Process}

Cleaning of $\mathrm{Si}$ wafer is essential in order to remove unwanted particles including metallic impurities, residues
[7]. In Bangladesh, raw wafer cleaning process was done in two steps. In the first step, sodium hydroxide $(\mathrm{NaOH})$ and DI water $\left(\mathrm{H}_{2} \mathrm{O}\right)$ was used. By adding $600 \mathrm{gm} \mathrm{NaOH}$ pellet with 6liters of DI water in a clean breaker, $10 \% \mathrm{NaOH}$ solution was made in the laboratory. To remove the organic contaminates from silicon wafer, the silicon wafer was dipped into $10 \% \mathrm{NaOH}$ solution with temperature $70^{\circ} \mathrm{C}$ for about 10 minutes. Then the wafers were ready for hydrophobic process. For this process; a solution diluted hydrofluoric acid was used and the ratio was $\mathrm{HF}: \mathrm{H}_{2} \mathrm{O}$ at 1 $\mathrm{ml}: 50 \mathrm{ml}$ respective volume. The wafers were dipped into the solution for 4 minutes in order to remove native oxide layer.

Figure 3 shows the SEM image of the (a) saw damaged silicon wafer surface and (b) saw damage removed silicon wafer surface.

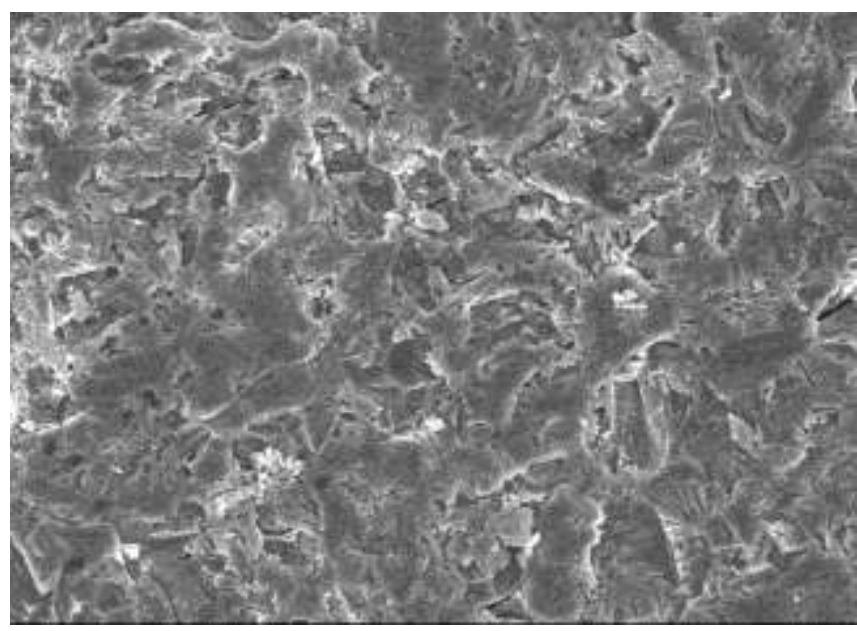

(a) Saw damaged silicon wafer surface.

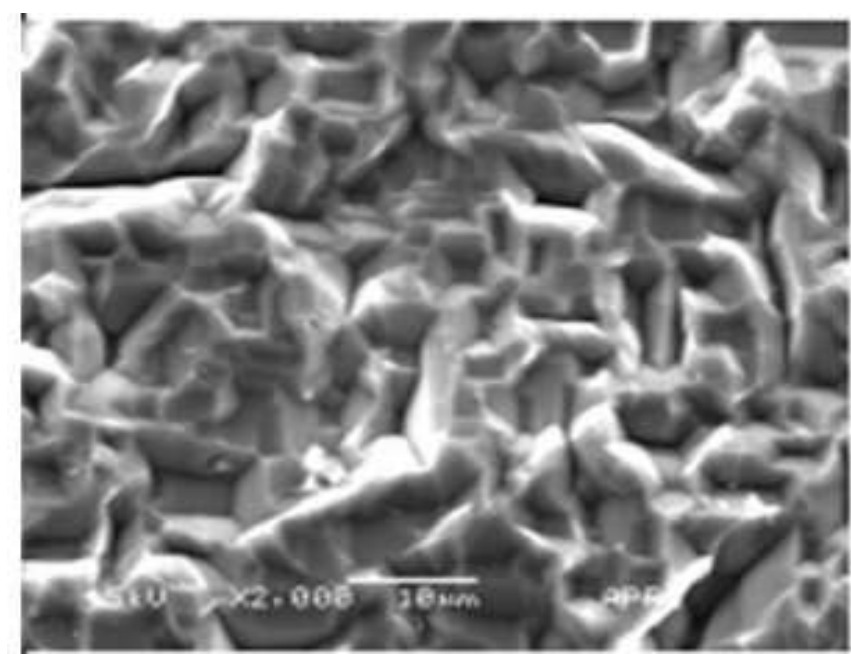

(b) Saw damage removed silicon wafer surface.

Fig- 3: SEM image of the (a) Saw damaged silicon wafer surface and (b) Saw damage removed silicon wafer surface.

\subsection{Texturing Process}

After saw damage removal process texturing on solar cell is done to reduce reflection and enhance light absorption [4], [5].In addition, surface texturing scatters light inside the 
semiconductor in order to trap it inside the wafer and thus increases efficiency of the solar cell. In this research, alkaline-based chemical were used for texturing process. The alkaline-based chemical solution was made by using $\mathrm{KOH}$, IPA and DI-water solution. The ratio of $\mathrm{KOH}$ (Potassium Hydroxide): IPA (Isopropyl Alcohol): $\mathrm{H}_{2} \mathrm{O}$ (DIwater) are 1 gram: $5 \mathrm{ml}$ : $125 \mathrm{ml}$. The wafers were dipped into the solution and heated at $70^{\circ} \mathrm{C}$ for 10 minutes.After 10minutespyramid structure was formed upon the surface of the wafer. Figure 4 shows the SEM images of textured surface of p-type silicon wafer.

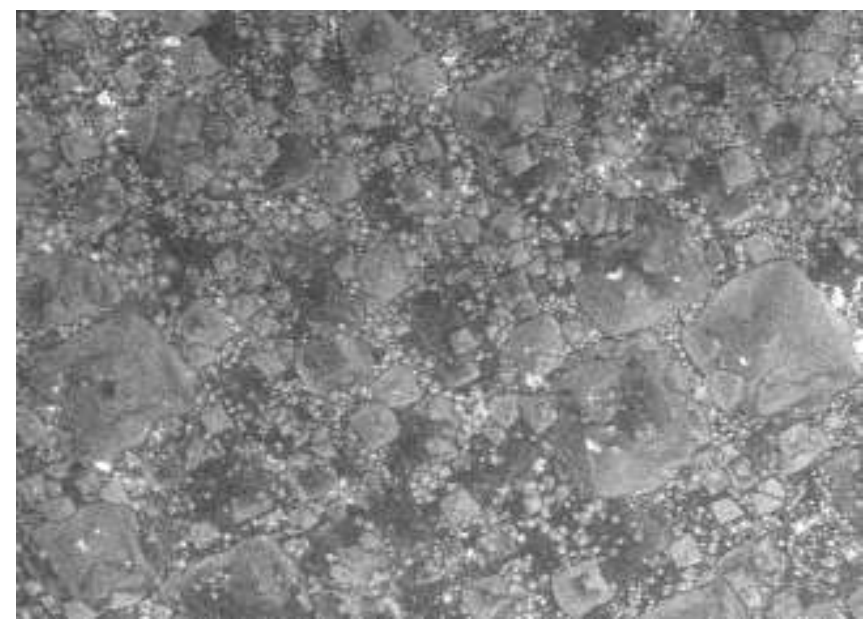

(a) 2000 times magnification

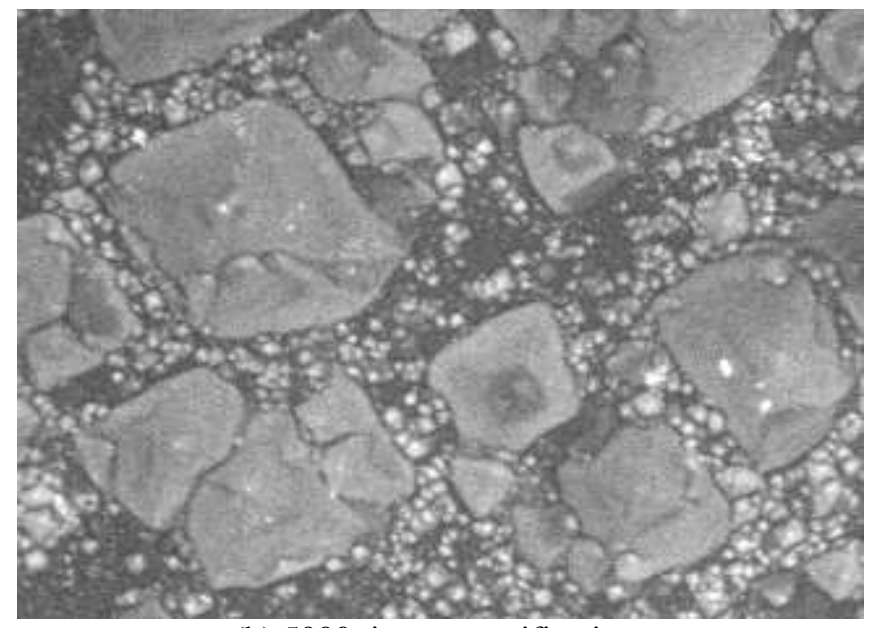

(b) 5000 times magnification

Fig- 4: SEM images of textured silicon wafer.

\subsubsection{Reflection of Texture Surface and Raw}

\section{Surface}

The variation of reflectance was observed using spectral response measurement system. From the measurements, it is seen that, the average reflectance for the surface of raw silicon wafer between the wavelength 675 to $1075 \mathrm{~nm}$ is 5.337619 AU and the same wavelength range the average reflectance for the texturing silicon wafer is $3.763397 \mathrm{AU}$. The difference of average reflectance between raw wafer and texturing wafer in the same range is 1.614222 AU. It is also seen from the graph the raw wafer surface reflectance is significantly higher than the texturing wafer and the maximum difference of surface reflectance at the wavelength $975 \mathrm{~nm}$ is $30.40 \%$.

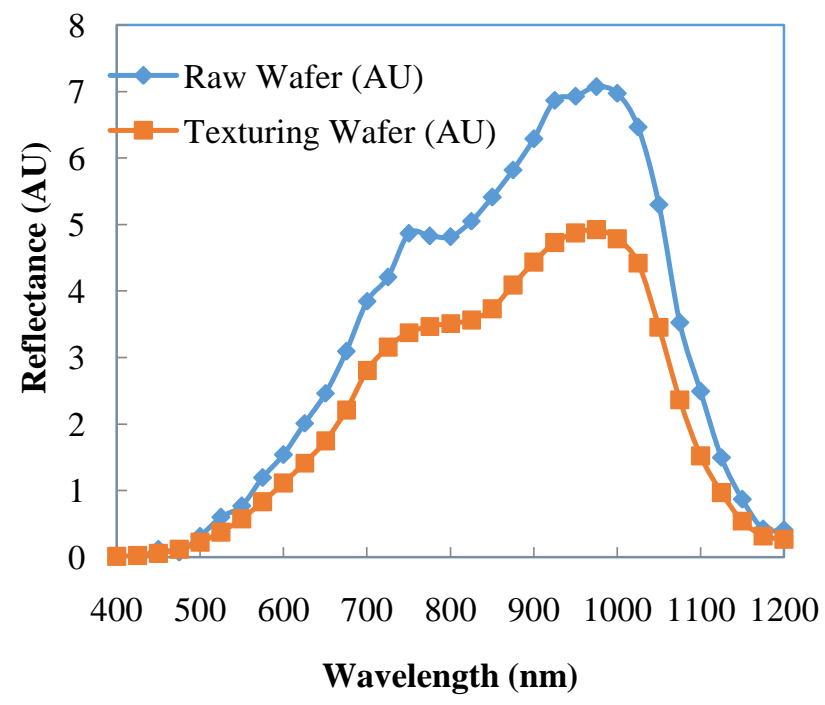

Fig 5: Plots of spectral reflection measurement of raw silicon wafer and textured wafer.

It can be concluded that the textured wafer is better for optical absorption which results high efficiency.

\subsection{Edge Isolation}

Edge isolation is a process that removes the phosphorous diffused area around the p-type wafer, so that the N-type layer is isolated from the P-type layer [8]. Edge isolation is absolutely necessary because the phosphorous diffused area around the p-type wafer acts as short for p-n junction of the solar cell and thus reduces the efficiency of solar cell. Here in Bangladesh for the edge isolation process, edge isolation paste was used before phosphorous diffusion.

After wafer cleaning and texturing process, the sides of the wafers were covered with edge isolation paste by a screen printing machine. Then the wafers were dried for 10 minutes in a preheated oven at $200{ }^{\circ} \mathrm{C}$.

\subsection{Diffusion Process}

There are many ways, that n-type layer can be formed upon p-type layer such as epitaxial growth, ion implantation, and diffusion [9]. In diffusion process phosphorus oxy chloride $\left(\mathrm{POCl}_{3}\right)$, oxygen $\left(\mathrm{O}_{2}\right)$ and nitrogen $\left(\mathrm{N}_{2}\right)$ gases are widely used to create n-type layer upon p-type silicon wafers. [10, 11]. In Bangladesh, for diffusion $\mathrm{POCl}_{3}, \mathrm{~N}_{2}$ and $\mathrm{O}_{2}$ gases were also used. The whole process is carried out in diffusion chamber at $850-900^{\circ} \mathrm{C}$. As $\mathrm{POCl}_{3}$ has a boiling temperature of $105.8{ }^{\circ} \mathrm{C}$ [12], it decomposes into $\mathrm{P}_{2} \mathrm{O}_{5}$ and reacts with $\mathrm{O}_{2}$, thus creating phosphosilicate glass (PSG) [SiO2:P2O5)x] layer upon silicon surface. After formation of PSG-Si interface, the phosphorus atoms penetrate through the Siwafer and diffusion happens [9].The following reaction happens during diffusion process: 


$$
\begin{gathered}
4 \mathrm{POCl}_{3}+3 \mathrm{O} 2_{2} \rightarrow 2 \mathrm{P}_{2} \mathrm{O}_{5}+6 \mathrm{Cl}_{2} \\
2 \mathrm{P}_{2} \mathrm{O}_{5}+5 \mathrm{Si} \rightarrow 4 \mathrm{P}+5 \mathrm{SiO}_{2} \\
\mathrm{P}+3 \mathrm{Si} \rightarrow \text { n-type dope } \mathrm{Si}
\end{gathered}
$$

\subsubsection{Sheet Resistance of Diffused Wafer}

After performing the doping of the wafers properly, the average value of sheet resistance of the wafers was calculated by taking resistivity measurement at different positions. All values are listed below. Table 1 shows the resistivity measurement at different positions of the $\mathrm{POCl}_{3}$ diffused wafer.

Table 1: Four point probe measurement on $\mathrm{POCl}_{3}$ diffused layer.

\begin{tabular}{|l|l|l|l|l|l|l|}
\hline Wafer & North & South & Center & West & East & $\begin{array}{l}\text { Average } \\
\mathrm{R}_{\mathrm{sh}}\end{array}$ \\
\hline $\begin{array}{l}\mathrm{POCl}_{3} \\
\text { diffuse } \\
\text { wafer }\end{array}$ & $\begin{array}{l}0.88 \\
\Omega-\mathrm{cm}\end{array}$ & $\begin{array}{l}0.96 \\
\Omega-\mathrm{cm}\end{array}$ & $\begin{array}{l}0.87 \\
\Omega-\mathrm{cm}\end{array}$ & $\begin{array}{l}0.93 \\
\Omega-\mathrm{cm}\end{array}$ & $\begin{array}{l}0.82 \\
\Omega-\mathrm{cm}\end{array}$ & $\begin{array}{l}0.88 \\
\Omega-\mathrm{cm}\end{array}$ \\
\hline
\end{tabular}

From the measurements, it is found that the average sheet resistance for diffused wafer is $0.88 \Omega-\mathrm{cm}$. This indicates the formation of n-type layer during diffusion process.

\subsection{Phosphosilicate Glass (PSG) Removals Process}

After diffusion Phosphosilicate glass (PSG) layer formed top of the Si-wafer surface at the temperature of $850^{\circ} \mathrm{C}$.Removalof the PSG layer from the silicon wafer surface was done using a $10 \%$ chemical solution of HF: $\mathrm{H}_{2} \mathrm{O}(10 \mathrm{ml}$ : 90ml) for 1 minute.

\subsection{Screen Printing Process}

Screen printing process is most commonly used to print metal contacts on back and front surfaces of solar cells. Silver past in front surface (n-type) and aluminum past in back surface (p-type) were used for screen printing process. Aluminum contact on the wafer backside also serves to form a heavily diffused $\mathrm{p}++$ layer that reduces contact resistance and creates back surface field.

\subsection{Rapid Thermal Annealing (RTA)}

The rapid thermal annealing (RTA) furnace was used to form permanent contacts by heating the screen printed contacts on silicon solar cells. Rapid thermal annealing is important because its forms low-resistance ohmic contacts and provides proper contact between the conductor and the semiconductor of solar cell.

In this research, RTA of screen printed cells was done in three temperature zones of $500^{\circ} \mathrm{C}, 600^{\circ} \mathrm{C}$ and $800{ }^{\circ} \mathrm{C}$ respectively.

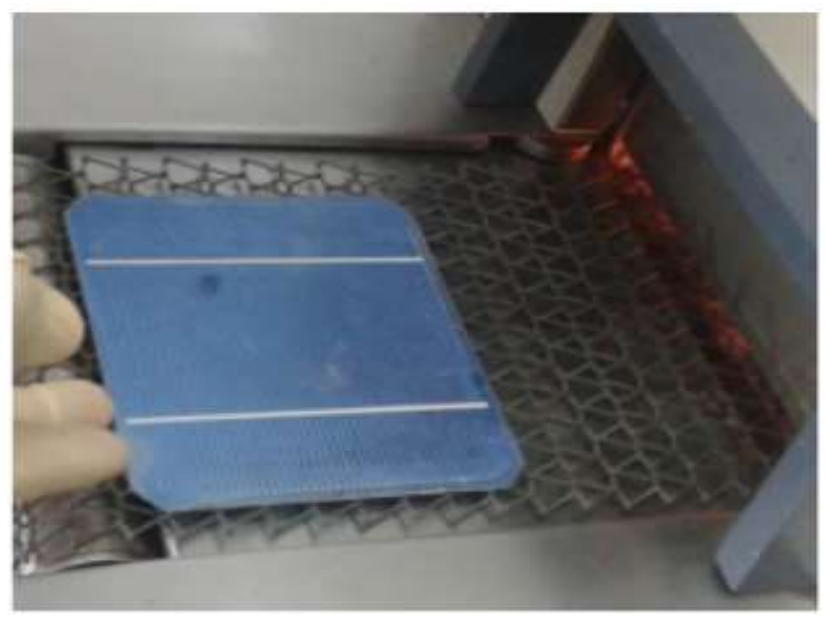

Fig- 6: Contact firing of solar cell in RTA furnace.

\section{RESULTS AND DISCUSSION}

Solar cells are characterized by their ability to convert sunlight into electricity. The light intensity (L), current (I) and voltage (V) test, which is also known as LIV test, determines open circuit voltage (Voc), short circuit current (Isc), maximum power (Pmax), fill factor (FF) and efficiency. Xenon-arc lamp was used in LIV testing as it is much closer to sunlight spectrum. LIV data are shown in Figure 7 , where light intensity was $150 \mathrm{~mW} / \mathrm{cm}^{2}$, with active surface area $161 \mathrm{~cm}^{2}$, and cell thickness of $200 \mu \mathrm{m}$.

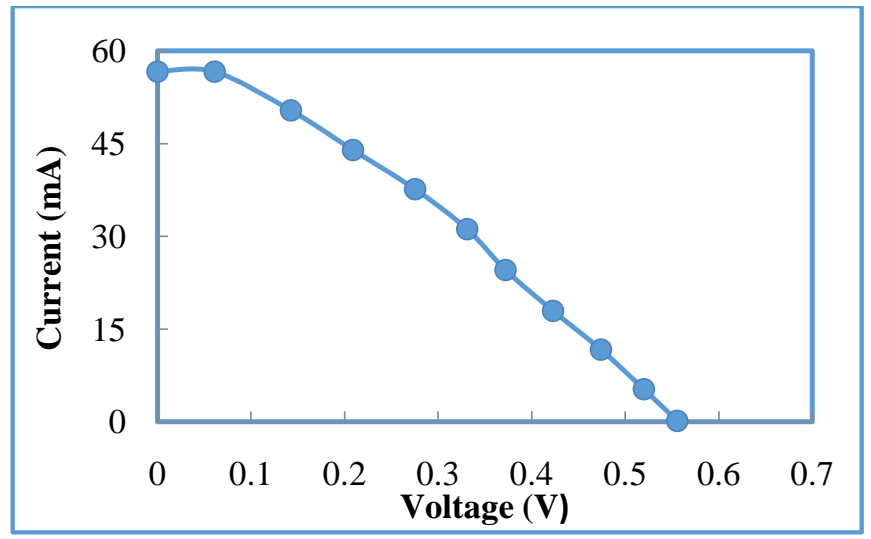

(a) Current-Voltage curve

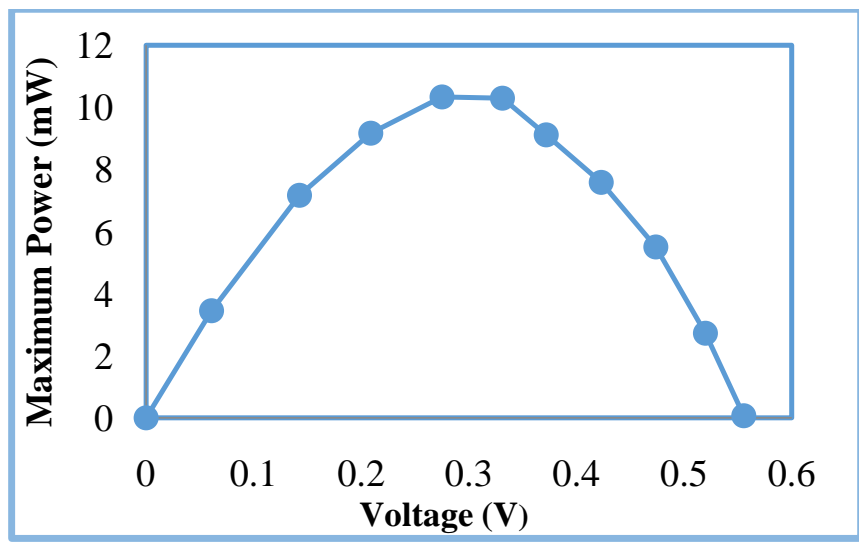

(b) $\mathrm{P}_{\max }-\mathrm{V}$ curve

Fig- 7: LIV measurement of a typical monofacial solar cell using Lab VIEW software 
From the LIV test, labview software provides I-V curve of fabricated solar cell. The following results were found in case of the fabricated monocrystalline silicon solar cell in Bangladesh. The data are, maximum power $\left(\mathrm{P}_{\max }\right)$ is $10.3369 \mathrm{~mW}$, maximum voltage $\left(\mathrm{V}_{\max }\right)$ is $0.27504 \mathrm{~V}$, maximum current $\left(\mathrm{I}_{\max }\right)$ is $37.5833 \mathrm{~mA}$, short circuit current is $\left(\mathrm{I}_{\mathrm{sc}}\right) 56.5867 \mathrm{~mA}$ and open circuit voltage $\left(\mathrm{V}_{\mathrm{oc}}\right)$ is $0.555462 \mathrm{~V}$.

\section{Fill factor (FF):}

$\mathrm{FF}=\mathrm{VmIm} /$ VocIsc

$=0.328868$

\section{Efficiency ( $\eta$ ):}

$\eta=$ Pout $/$ Pin

$=[($ VocIsc $\times$ FF $) /$ Pin $] \times 100 \%$

$=6.89 \%$. $\left[\mathrm{P}_{\mathrm{in}}=150 \mathrm{~mW} / \mathrm{cm}^{2}\right]$

The efficiency obtained from the experiment was $6.89 \%$.

\section{CONCLUSION}

The fabrication of monocrystalline silicon solar cell was done in Bangladesh Atomic Energy Commission (BAEC) and the efficiency of solar cell was found $6.89 \%$. Although, it is less efficient than the commercially available solar cell in the market, the main objective of this research was to fabricate and study monocrystalline silicon solar cell in Bangladesh, which is why the low efficiency was accepted and tried to find out the challenges and its remedy to increase the solar cell efficiency. The main challenges are now to find right wet chemical recipe, determine the flow rates and timing of the gases in the diffusion chamber, doping concentration and optimum temperature zones in the rapid thermal annealing furnace. In summary, momentous knowledge about fabricating monocrystalline silicon solar cells has been achieved. Priority should be given to find out the problems for achieving low efficiency and optimizing the parameters and equipment's to improve the efficiency of solar cell. Thus promoting and developing fabrication technology of solar cell in the country.

\section{ACKNOWLEDGEMENT}

The authors want to thank Bangladesh Atomic Energy Commission, for giving access to the only solar cell fabrication laboratory at Savar, Bangladesh to do research in the solar cell fabrication laboratory, and also providing logistics support.

\section{REFERENCES}

[1] Energy Information, (EIA)Energy Information Administration, US, Available: http://www.eia.gov

[2] $\mathrm{CO}_{2}$ generation data, Earth's $\mathrm{CO}_{2}$ Home page, Available: https://www.co2.earth/

[3] J. F. Nijs, J. Szlufcik, J. Poortmans, S. Sivoththaman and R. P. Mertens, "Advanced Manufacturing Concepts for Crystalline Silicon Solar Cells," IEEE Transaction on Electron Devices, vol. 46, pp. 948- 969. 1999.
[4] S. M. Iftiquar, Y. Lee, M. Ju, N. Balaji, S. K. Dhungel and J. Yi, "Fabrication of Crystalline Silicon Solar Cell with Emitter Diffusion, SiNx Surface Passivation and Screen Printing of Electrode", "Photodiodes - From Fundamentals to Applications", ISBN 978-953-510895-5,

[5] C.S. Leong, N. Amin, M.Y. Sualiman, A. Zaharim, K. Sopian and S. H. Zaidi, "Some Key Issues In the Processing and Fabrication of Higher Efficiencies Silicon Solar Cells", Proceedings of the 3rd WSEAS International Conference on Renewable Energy Source, pp.305.

[6] Mrwa, G. Ebest, M. Rennau and A. Beyer, "Comparison of Different Emitter Diffusion Methods for MINP Solar Cells: Thermal Diffusion and RTP," Solar Energy Materials \& Solar Cells, vol. 61no. 2, pp. 127- 134, 2000.

[7] Tom Markvart, 1994.Solar Electricity. UK: Jhon Wiley and Sons.

[8] Galib Hashmi, Md. AbdurRafiqAkand, Mohammad Khairul Basher, MahbubulHoq and Md. Habibur Rahman, "Fabrication of Crystalline Silicon Solar Cell in Bangladesh: Limitations and Remedies", International Journal of Scientific \& Engineering Research, Volume 7, Issue 5, 2016.

[9] Bultman J, Cesar I, Geerligs B, Komatsu Y, Sinke W, Method of Emitter formation for crystalline silicon solar cells, The Journal of Photovoltaic International;2010; 8:69-81.

[10] Nakaya H, Nishida M, Takeda Y, Moriuchi S, Tonegawa T, Machida T, Nunoi T, Poly crystalline silicon solar cells with Vgrooved surface, Solar Energy Materials and Solar Cells;1994;34:219-225.

[11] Rohatgi A, Chen Z, Sana P, Crotty J, Salami J, High Efficiency multi-crystalline silicon solar cells, Solar Energy Materials and Solar Cells;1994; 34:227-236.

[12] Greenwood NN, Earnshaw A, Chemistry of the Elements, 2nd ed., Butterworth-Heinemann, Oxford, UK, 1997.

[13] Micard G, Dastgheib-Shirazi A, Steyer M, Wagner H, Altermatt P, Hahn G, Advances in the understanding of phosphorus silicate glass (PSG) formation for accurate process simulation for phosphorus diffusion, 27th EUPVSEC; 2012;24-28, 2012.

[14] Gangopadhyayet al.2007. Comparative study of different approaches of multi-crystalline silicon texturing for solar cell fabrication. Solar Energy Materials and Solar Cell 91(4):180-185.

[15] Moreno et al.2010. Dry fabrication process for heterojunction solar cells through in-situ plasma cleaning and passivation. Solar Energy Materials and Solar Cell 94:402.

[16] Maneaet al.2005 Optimization of front surface texturing processes for high efficiency silicon solar 
cells. Solar Energy Materials and Solar Cell87: 423431.

[17] Kaiser et al.1991 Texturing Etching of multi-crystalline silicon. Proc 10th EC Photovoltaic Solar Energy Conference, pp. 111-116.

[18] Zhao et al.1999A 19.8\% Efficient Honeycomb MultiCrystalline Silicon Solar Cell with Improved Light Trapping. IEEE Transaction On Electron Device 46(10): 1978-1983.

[19] Yurokhovet al.2002Solar Energy and Human Settlement, pp. 1520-1523.

[20] Matthew et al.2008 Effect of texturing and surface preparation on lifetime and cell performance in hetero junction silicon solar cells. Solar Energy Materials and Solar Cell 92: 1373-1377. 